\title{
Burden of neurological and neurocognitive impairment in pediatric sickle cell anemia in Uganda (BRAIN SAFE): a cross-sectional study
}

Nancy S. Green ${ }^{1 *}$ (D), Deogratias Munube ${ }^{2}$, Paul Bangirana ${ }^{3}$, Linda Rosset Buluma ${ }^{2}$, Bridget Kebirungi ${ }^{2}$, Robert Opoka², Ezekiel Mupere ${ }^{2}$, Philip Kasirye ${ }^{2}$, Sarah Kiguli ${ }^{2}$, Annet Birabwa ${ }^{3}$, Michael S. Kawooya ${ }^{4}$, Samson K. Lubowa ${ }^{4}$, Rogers Sekibira ${ }^{2}$, Edwards Kayongo ${ }^{2}$, Heather Hume ${ }^{5}$, Mitchell Elkind ${ }^{6}$, Weixin Peng ${ }^{7}$, Gen $\mathrm{Li}^{7}$, Caterina Rosano ${ }^{8}$, Philip LaRussa ${ }^{9}$, Frank J. Minja ${ }^{10}$, Amelia Boehme $^{11}$ and Richard Idro ${ }^{2}$

\begin{abstract}
Background: Children with sickle cell anemia (SCA) are highly susceptible to stroke and other manifestations of pediatric cerebral vasculopathy. Detailed evaluations in sub-Saharan Africa are limited.

Methods: We aimed to establish the frequency and types of pediatric brain injury in a cross-sectional study at a large SCA clinic in Kampala, Uganda in a randomly selected sample of 265 patients with HbSS ages 1-12 years. Brain injury was defined as one or more abnormality on standardized testing: neurocognitive impairment using an age-appropriate test battery, prior stroke by examination or transcranial Doppler (TCD) velocities associated with stroke risk in children with SCA (cerebral arterial time averaged mean maximum velocity $\geq 170 \mathrm{~cm} / \mathrm{second}$ ).

Results: Mean age was $5.5 \pm 2.9$ years; $52.3 \%$ were male. Mean hemoglobin was $7.3 \pm 1.01 \mathrm{~g} / \mathrm{dl} ; 76.4 \%$ had hemoglobin $<8.0 \mathrm{~g} / \mathrm{dl}$. Using established international standards, $14.7 \%$ were malnourished, and was more common in children ages 5-12. Overall, 57 (21.5\%) subjects had one to three abnormal primary testing. Neurocognitive dysfunction was found in 27, while prior stroke was detected in 15 (5.7\%). The most frequent abnormality was elevated TCD velocity 43 (18.1\%), of which five (2.1\%) were in the highest velocity range of abnormal. Only impaired neurocognitive dysfunction increased with age (OR 1.44, 95\% Cl 1.23-1.68), $p<0.001$ ). In univariate models, malnutrition defined as wasting (weight-for-height $\leq-2$ SD), but not sex or hemoglobin, was modestly related to elevated TCD (OR 1.37, 95\%Cl 1.01$1.86, p=0.04)$. In adjusted models, neurocognitive dysfunction was strongly related to prior stroke (OR $6.88,95 \% \mathrm{Cl}$ $1.95-24.3, p=.003)$ and to abnormal TCD (OR 4.37,95\%Cl 1.30, $p=0.02)$. In a subset of 81 subjects who were enriched for other abnormal results, magnetic resonance imaging and angiography (MRI/MRA) detected infarcts and/or arterial stenosis in 52\%. Thirteen subjects (25\%) with abnormal imaging had no other abnormalities detected.

Conclusions: The high frequency of neurocognitive impairment or other abnormal results describes a large burden of pediatric SCA brain disease in Uganda. Evaluation by any single modality would have underestimated the impact of SCA. Testing the impact of hydroxyurea or other available disease-modifying interventions for reducing or preventing SCA brain effects is warranted.
\end{abstract}

Keywords: Sickle cell anemia, Stroke, Neurocognitive impairment, Transcranial doppler, Sub-Saharan Africa

\footnotetext{
* Correspondence: NSG11@CUMC.Columbia.edu

'Department of Pediatrics, Columbia University Vagelos Medical Center, 630

West 168 St., Black Building 2-241, Box 168, New York, NY, USA

Full list of author information is available at the end of the article
}

(c) The Author(s). 2019 Open Access This article is distributed under the terms of the Creative Commons Attribution 4.0 International License (http://creativecommons.org/licenses/by/4.0/), which permits unrestricted use, distribution, and

reproduction in any medium, provided you give appropriate credit to the original author(s) and the source, provide a link to the Creative Commons license, and indicate if changes were made. The Creative Commons Public Domain Dedication waiver (http://creativecommons.org/publicdomain/zero/1.0/) applies to the data made available in this article, unless otherwise stated. 


\section{Background}

Approximately 225,000 children with sickle cell anemia (SCA) are born in sub-Saharan Africa each year [1]. In Uganda, 15,000-20,000 affected infants are born annually, most with homozygous SCA (HbSS) [2].

In affected children, SCA brain vasculopathy may cause overt stroke, primarily ischemic in nature, starting early in childhood. Without preventative measures, children with $\mathrm{HbSS}$ are 200-fold more susceptible to stroke compared to the general pediatric population [3]. Prior to implementation of prevention strategies, frequency of childhood stroke in the U.S. and Jamaica was $5-10 \%$, with first stroke in early childhood [3-5]. Vasculopathy of subcortical or small vessels in SCA may also cause silent cerebral infarction (SCI), lacking an associated neurologic event. At times, one or more SCI may manifest as neurocognitive dysfunction [6-12].

The large number of children with SCA in subSaharan Africa, coupled with high frequency of stroke risks such as severe anemia and limited available medical resources contribute to a high burden of sickle cerebral vasculopathy and associated SCA brain injury [13-15]. Targeted stroke prevention employs risk assessment by transcranial doppler (TCD) to detect abnormal flow in large cerebral arteries, but is rarely available in the region [6]. Systematic multi-modal evaluations of structural or functional impact of pediatric sickle cerebral vasculopathy in sub-Saharan Africa have been limited [16-24]. Previous brain imaging studies by computed tomography or magnetic resonance (MRI) have been rare and small in scope [25].

We aimed to determine the frequency and characteristics of neurocognitive and neurological abnormalities of young children in a randomly selected sample from a large SCA clinic in Kampala for the study "Burden and Risk of Neurological and Neurocognitive Impairment in Pediatric Sickle Cell Anemia in Uganda (BRAIN SAFE)."

\section{Methods}

Study design

BRAIN SAFE was a cross-sectional study of children with confirmed $\mathrm{HbSS}$ (or $\mathrm{HbSB}^{0}$ thalassemia) receiving care from the SCA clinic at Mulago Hospital in Kampala, Uganda. Approximately 3500 patients actively receive care at this clinic and are included in the clinic's electronic clinical database [26]. Study documents used for caretakers and subjects were written in English and translated into Luganda, a predominant local language, by a certified translator, then reviewed by the study team for accuracy.

\section{Eligibility, recruitment, screening and enrollment}

Study inclusion criteria: ages 1-12 years, prior clinical laboratory documentation of SCA (HbSS or $\mathrm{HbS}-\mathrm{B}^{0}$ thalassemia) by standard hemoglobin electrophoresis, prior SCA clinic appointments (or one appointment for age $\leq 2)$, hemoglobin $(\mathrm{Hb}) \geq 6.0 \mathrm{~g}$ per deciliter $(\mathrm{g} / \mathrm{dl})$ (HemoCue AB, Sweden). Additional inclusion criteria were absence of an acute crisis, acute illness with fever or respiratory infection over the preceding 2 weeks per parental report, or blood transfusion during the preceding 3 months.

\section{Exclusion criteria}

history of neurological impairment prior to age 4 months to help avoid subjects with non-SCA neurological events (e.g. complicated birth, neonatal brain injury), study participation of a sibling, past or concurrent enrollment in a clinical intervention study or history of hydroxyurea use.

Sample size was determined by age trends for SCI detected by magnetic resonance imaging (MRI) in U.S. and French children with SCA. SCI is the most common type of early brain vascular injury detected by MRI, is associated with cognitive dysfunction, and generally is not prevented by TCD screening [6]. Based on the estimated frequency of SCA cerebral vasculopathy of $20 \%$ within the study age range from elsewhere, [6] 80\% power within a $95 \%$ confidence interval, the target sample size was 246. To account for an estimated $8 \%$ incomplete testing due to attrition, logistics or death, study entry was offered to 265 sequentially eligible participants.

\section{Subject selection and assessment}

From the clinic's electronic clinical database, patients with correct study ages and who had attended clinic at least once in the prior 12 months were randomly assigned a study number from the electronic SCA clinic roster at Mulago Hospital (Fig. 1), where 2230 children with SCA were registered in the clinical database [27]. Study numbers were randomly assigned to the 1048 active patients ages 1-12 years. Among those, parents or guardians of a random sample of 400 were sequentially telephoned by the study nurse to mention the study and invite the child to the clinic for screening. This process was repeated until the target enrollment number was achieved. Patients meeting all criteria were offered enrollment. Written parental consent and (if applicable) assent (for children 8 years or older) were obtained.

Demographic (sex, age) and clinical (Hb, anthropometry) variables were collected at enrollment, as was a detailed SCA history. Stroke examination and TCD measurement were also performed on the day of enrollment. Other testing, described below, were performed by appointment at other study visits. Detailed patient histories for prior strokes or other complications and hospitalizations, had not been routinely recorded in the clinical database or other medical source document. Hence medical history was not included in this report. 
2230 children ages $1-12$ years in the Mulago Hospital Sickle Cell clinical database

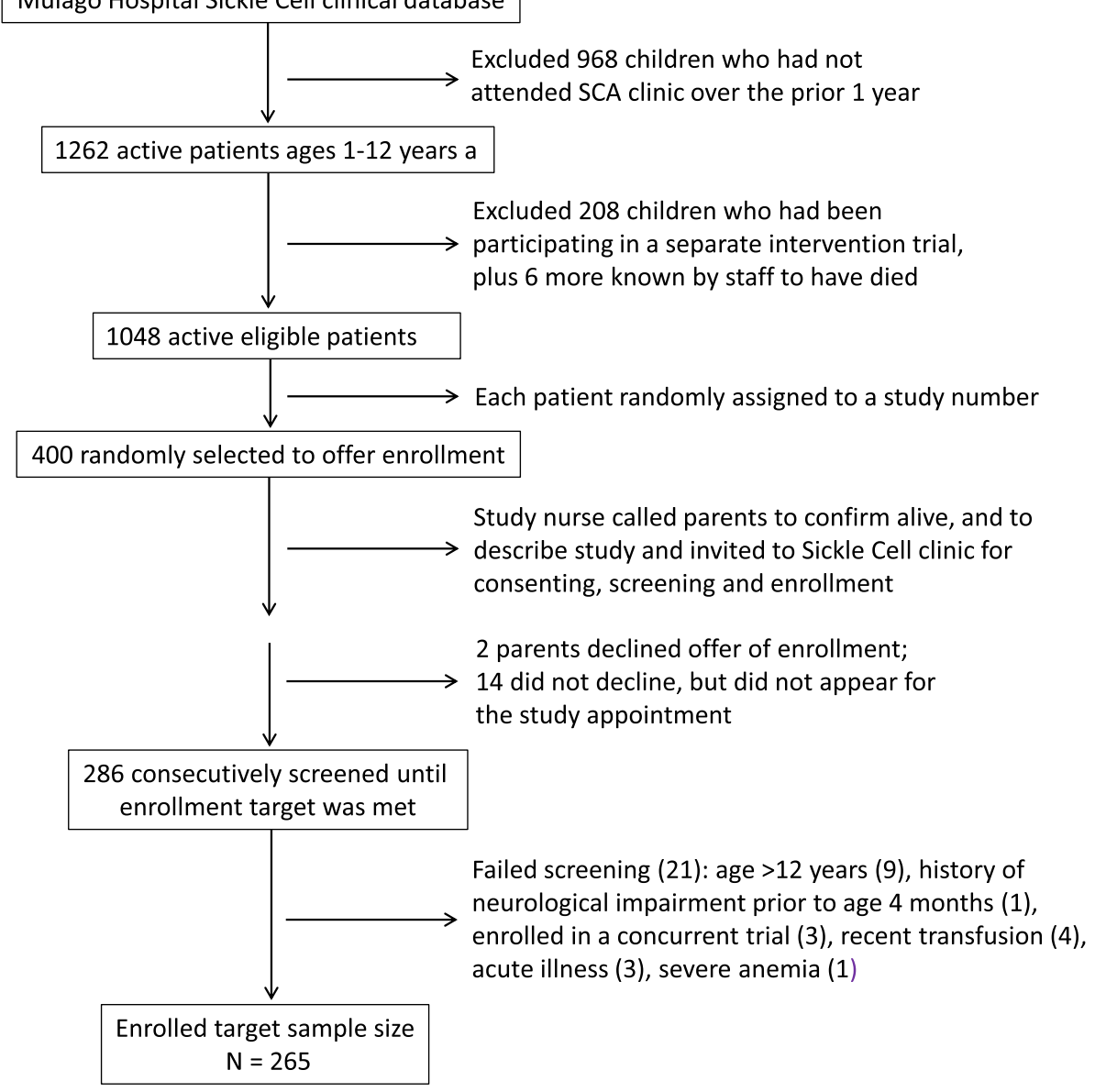

Fig. 1 Flow chart for subject recruitment and enrollment

\section{Anthropometric assessment}

Study staff determined routine height or length and weight measurements according to World Health Organization (WHO) standard procedures for growth monitoring of delayed or inadequate growth [28]. "Using established international pediatric standards, the WHO defines "wasting," a type of malnutrition, as weight-for-height/length $\mathrm{z}$-scores or BMI of $\leq-2 \mathrm{SD}$, by age and sex, for children younger or older than age 5 years, respectively. Severe wasting is defined as z-scores of $\leq-3 S D$ [28].

In children 2 years or older, the standing (upright) height was determined using a portable stadiometer. For children $<2$ years or those unable to stand upright, recumbent length was measured. Weight was determined using a calibrated digital scale. These anthropometric measures were selected to reduce influence from disease-associated delayed growth and development that are frequently found in pediatric SCA across resource settings [16, 29].

\section{Hematological assessment}

Following enrollment, a complete blood count (CBC) was obtained and assayed by the hospital's central laboratory using standard parameters.

\section{Neurocognitive and neurologic results}

Subjects underwent three different standardized neurologic or neurocognitive assessments to detect abnormal findings in one or more assessment. A selected subset underwent a fourth assessment, described below.

\section{Neurocognitive testing}

A standardized age-appropriate test battery was administered to each subject on a separately scheduled day by testers who were experienced in the materials used. Test materials had been previously translated into and validated in Luganda [30-34]. Testing and scoring were performed by trained, experienced testers who were closely supervised by a senior study team member. Testing was performed at a separate study visit to avoid participant 
fatigue. Subjects ages 1-4 years underwent testing using the Mullen Scales of Early Learning, testing for gross and fine motor skills, expressive and receptive language, and visual reception $[35,36]$. Subjects aged 5-12 years were tested using the Kaufman Assessment Battery for Children, 2nd edition (KABC-II), testing for short- and long-term memory, reasoning, ability and visual processing $[37,38]$. In each test, summation of subscales generated an overall score of neurocognitive ability. Abnormal results were defined as $\leq-2$ z-scores below age-specific established community norms, based on previously determined data for children without SCA within the same age range: 106 controls for the KABC-II and 149 for the Mullen [30, 33].

\section{Stroke assessment}

The standardized well-validated pediatric NIH Stroke Scale, PedNIHSS, was used for documenting prior stroke in children ages 2-18 years. PedNIHSS scores are assigned to define the presence and degree of stroke findings: 0 (no stroke), 1-4 (mild stroke), 5-15 (moderate stroke), 16-20 (moderately severe stroke) or 21-42 (severe stroke) [39, 40]. Testing was performed by a study staff physician following training and initial direct supervision by the study pediatric neurologist. Parental report was not used to identify subjects with prior stroke, as subject histories had not been medically documented. While seizures can be associated with SCD stroke in the West, [41] seizures from endemic CNS infections are more common in sub-Saharan Africa [42].

\section{TCD velocity}

Non-imaging TCD standardized for pediatric SCA was performed on subjects ages $\geq 2$ years by two study staff using a single machine (SonaraTek, Natus, U.S.). Subjects undergoing testing were afebrile, awake, and did not have a recent acute illness. Arterial time-averaged maximum mean velocities (TAMV) were performed bilaterally over the middle (MCA), anterior and posterior cerebral (PCA) and internal carotid arteries (ICA) [43]. Increased stroke risk with elevated flow velocities in one or more arteries tested, defined by standardized criteria as elevated: conditional ( $\geq 170-<200 \mathrm{~cm} /$ second) or abnormal $(\geq 200 \mathrm{~cm} / \mathrm{second})$, or very low, predicts high SCA stroke risk in children ages 2-16 years [43, 44]. Very low TAMV $(<70 \mathrm{~cm} / \mathrm{s})$, excluding the PCA and distal ICA, is also a risk factor for stroke [46]. TCD was considered to be inadequate if readings did not include a minimum of TAMV for bilateral MCA and internal carotid arteries [47].

\section{Training and tester reliability}

Training, supervision and quality assurance were performed [43]. The intra-class correlation coefficient statistic was used to assess reliability between the two testers following their training and supervision, per Galadanci et al. [45]

(See Additional file 1.)

\section{TCD protocol}

Per standardized approach, subjects with initial abnormal or conditional velocities underwent repeated testing within 1-3 months [43, 47]. Upon re-testing, subjects with persistent abnormal or TCD velocities were referred to SCA clinic for initiating hydroxyurea therapy, per the clinic's standardized protocol for dosing and monitoring [27].

\section{Brain MRI/MRA imaging}

Non-contrast imaging was performed on a $1.5 \mathrm{~T}$ scanner (1.5 T Achieva MRI equipment from Philips Medical Systems, Netherlands). Based on available study budget, a $30 \%$ subset of subjects $(N=81)$ underwent $\mathrm{MR}$ imaging. To investigate the correlation between imaging markers and abnormal testing, this subset was intentionally oversampled for having abnormal test results in at least one of the three primary evaluations. The subset included 61 participants with abnormal testing, with 20-25 each with abnormal TCD or cognitive impairment, and 14 of the 15 with prior stroke, plus 20 who had normal test results in all three domains. Selection for MR imaging was made irrespective of age or sex.

Scans were performed on medically stable subjects. Oral sedation by chloral hydrate was used if needed for agitation. Standard clinical imaging interpretation was performed by two study radiologists who were blinded to other study results. Size of infarct and arterial stenosis were determined for pediatric SCA $[46,48]$.

\section{Data management}

An electronic study database was developed by and housed on a secure server using EPI-DATA version 3.1 software package (The EpiData Association, Odense, Denmark) by Global Health Uganda.

\section{Statistical analyses}

Primary abnormal results were a documentation of prior stroke on the PedNIHSS stroke exam, an impaired neurocognitive test result on the Mullen's or KABC II test compared to historical community controls or TAMV by TCD outside of the normal range for pediatric SCA (conditional or abnormal), reported as proportions. Relationships between the sample characteristics and the results were examined by ANOVA or chi square tests, as appropriate. A 2-tailed probability test was used, with statistically significant $P$-values defined by <.05. Logistic regression was used for multivariate analyses. Each model was run with the maximum sample size possible when some covariates were not collected. Analyses were conducted using IBM SPSS 
Statistics (version 25, NY). Standardized mortality ratio was used to estimate rates of mortality and stroke over the brief observational period [49].

\section{Results}

\section{Sample description}

Of 400 randomly selected patients eligible by diagnosis and age, study enrollment was offered until reaching the enrollment target of 265 (Fig. 1). Two parents declined enrollment outright, while 14 did not attend the study appointment and declined further telephone calls from study staff. Of 286 patients screened, 265 were eligible (92.3\%), and all of these enrolled. Ineligibility was due to age $>12$ years (9), recent transfusion (4), current acute illness (3), screened $\mathrm{Hb}<6.0$ (1), history of early neurologic impairment (1), participation in another concurrent study (3), or unrecorded reason (1). Among enrolled participants, mean age was $5.5 \pm 2.9$ years (Table 1 ); over half were pre-school. Children ages $1-4$ and 5-8 years each constituted $40.7 \%$ of the sample, while subjects ages 9-12 years were $18.6 \%$. The sample was $52.5 \%$ male.

\section{Hematological and anthropometric assessment}

Mean $\mathrm{Hb}$ was $7.3 \pm 1.01 \mathrm{~g} / \mathrm{dl}$. (Table 1 ), with $76.4 \%$ having severe anemia, defined as $<8 \mathrm{~g} / \mathrm{dl}$ (National Cancer Institute CTCAE Version 5.0, 2017). Although all participants were screened by Hemacue for $\mathrm{Hb} \geq 6.0 \mathrm{~g} / \mathrm{dl}$, lower $\mathrm{Hb}$ was detected by $\mathrm{CBC}$ in 19 (7.6\%). Of them, 18 had $\mathrm{Hb} 5.0-5.9 \mathrm{~g} / \mathrm{dl}$, one had $4.6 \mathrm{~g} / \mathrm{dl}$. No subjects had reported acute symptoms of anemia.

Using WHO definitions and standards by age and sex, 37 of 252 participants with adequate measurement
(14.7\%) were malnourished, with $\mathrm{z}$-scores of $\leq-2$ (Table $1)$. Older subjects ages $5-12$ years were more affected by malnutrition: 27 of 144 (18.8\%). Among these, nine (6.3\%) were severely malnourished, with z-scores of $\leq-3$. In contrast, among subjects ages 1-4, 10 of 108 (9.3\%) were malnourished; three $(2.8 \%)$ were severely malnourished.

\section{Neurocognitive and neurological results}

Overall, 57 (21.5\%) subjects had one or more abnormal results detected (Table 2). The subset with abnormal MRI/MRA despite normal testing added an additional $5.7 \%$ detected pathology.

\section{Neurocognitive testing}

The parents of 21 participants refused to return for a separate study appointment; their children missed testing. Using age-specific locally standardized test scoring, 27 of 244 subjects tested (11.1\%) had abnormal subscale summary scores: 3 of 100 (3.0\%) ages $1-4$ and 25 of 144 (16.7\%) ages 5-12. (Table 2).

\section{Stroke assessment}

Standardized PedNIHSS [40] revealed that 15 of 262 (5.7\%) had an abnormal neurological examination consistent with prior stroke. (Table 2) Nine subjects had unilateral stroke findings in the minor range (scale 1-4), and six within the moderate range (515). The two highest stroke scores were 14 and 15 , which fall within the highest levels within the moderate range [39]. Age of subjects with stroke findings did not differ from age distribution of the entire

Table 1 Sample characteristics of 265 subjects with SCA, ages 1-12 years

\begin{tabular}{|c|c|c|c|}
\hline & $\begin{array}{l}\text { Total Mean } \pm \text { SD } \\
N=265(\%)\end{array}$ & $\begin{array}{l}\text { Ages } 1-4 \text { years } \\
\text { Mean value } \pm \text { SD } \\
N=113(\%)\end{array}$ & $\begin{array}{l}\text { Ages } 5-12 \text { years } \\
\text { Mean value } \pm S D \\
N=152(\%)\end{array}$ \\
\hline Age (years) & $5.5 \pm 2.9$ & $2.5 \pm 1.1$ & $7.5 \pm 2.1$ \\
\hline Sex (male), N (\%) & $139(52.4)$ & $61(54.0)$ & $77(50.6)$ \\
\hline Height $(\mathrm{cm})(N=252)$ & $109.3 \pm 18.0$ & $92.0 \pm 13.7$ & $121.6 \pm 11.9$ \\
\hline Weight (kg) (N = 252) & $18.1 \pm 6.1$ & $13.8 \pm 9.6$ & $22.7 \pm 12.6$ \\
\hline Malnutrition $^{+}(\mathrm{N}=252), \mathrm{N}(\%)$ & $37(14.7)$ & $10(9.3)$ & $27(18.8)$ \\
\hline Severe malnutrition $^{++}, \mathrm{N}(\%)$ & $12(4.8)$ & $3(2.8)$ & $9(6.3)$ \\
\hline Malnutrition (z-score) & $-0.82 \pm 1.52$ & & \\
\hline Weight-for-height (z-score) & - & $-0.49 \pm 1.75$ & - \\
\hline BMI z-score & - & - & $-1.06 \pm 1.27$ \\
\hline Hemoglobin" $(g / d l)(N=250)$ & $7.3 \pm 1.0$ & - & - \\
\hline $\mathrm{Hb} \leq 7.5 \mathrm{~g} / \mathrm{dl}(\mathrm{N}=158)$ & $6.7 \pm 0.5$ & $6.6 \pm 0.6$ & $6.7 \pm 0.5$ \\
\hline $\mathrm{Hb}>7.5 \mathrm{~g} / \mathrm{dl}(N=92)$ & $8.3 \pm 0.7$ & $8.4 \pm 0.7$ & $8.3 \pm 0.8$ \\
\hline
\end{tabular}

${ }^{+}$Defined per World Health Organization standards, by age and sex, for children $1-4$ years and ages $5-12$ years, as $z$-score of $\leq-2$; ${ }^{++} z$-score of $\leq-3$. (ref. 28 ) "Severe anemia is defined as $\mathrm{Hb}<8.0 \mathrm{~g} /$ deciliter (National Cancer Institute CTCAE Version 5.0, 2017)

Over half of the participants in the BRAIN SAFE cross-sectional sample were pre-school age. Participants were divided into two age groups to align with the neurocognitive testing batteries used for these two age ranges. Malnutrition (low weight-for-height) was highly prevalent, especially among those ages $5-12$ years. Hemoglobin levels were low and did not vary by age 
Table 2 Proportion of subjects affected by abnormal results in one or more of the three primary tests performed, overall and by age group

\begin{tabular}{|c|c|c|c|}
\hline & $\begin{array}{l}\text { Entire Cohort } \\
\text { Mean value } \\
(\mathrm{N}=265)\end{array}$ & $\begin{array}{l}\text { Ages } 1-4 \text { years } \\
\text { Mean value } \\
N=113(\%)\end{array}$ & $\begin{array}{l}\text { Ages } 5-12 \text { years } \\
\text { Mean value } \\
N=152(\%)\end{array}$ \\
\hline Any of the 3 tests performed & $57(21.5 \%)$ & $22(23.7 \%)$ & $43(31.2 \%)$ \\
\hline Mean age for any abnormality (SD) & $6.17(3.3)$ & $2.45(0.74)$ & $8.07(2.32)$ \\
\hline Prior stroke $(\mathrm{N}=265)$ & $15(5.7 \%)$ & $3(3 \%)$ & $12(8.5 \%)$ \\
\hline Mean age for prior stroke (SD) & $6.4(2.56)$ & $2.33(0.58)$ & $7.42(1.62)$ \\
\hline Elevated TCD $(N=251)$ & $43(17.1 \%)$ & $17(18.9 \%)$ & $18(13.6 \%)$ \\
\hline Abnormal TCD $(N=5)$ & $5(2.0 \%)$ & $1(1 \%)$ & $3(2 \%)$ \\
\hline Conditional TCD $(N=38)$ & $38(15.1 \%)$ & $20(20 \%)$ & $18(12.3 \%)$ \\
\hline Mean age for elevated TCD (SD) & $4.92(3.18)$ & $2.38(0.74)$ & $7.48(2.56)$ \\
\hline Neurocognitive Dysfunction $(N=246)$ & $27(11.0 \%)$ & $5(5 \%)$ & $22(15.5 \%)$ \\
\hline Mean age for neurocognitive dysfunction (SD) & $8.04(3.12)$ & $2.60(0.89)$ & $9.27(1.80)$ \\
\hline
\end{tabular}

One in five participants $(57$ of $265,21.5 \%)$ had at least one abnormal result in the three tests performed. The most frequent findings were elevated TCD velocity and neurocognitive dysfunction

Table 3 Uni- and multi-variate analyses for study variables assessed for each of the three primary tests performed: neurocognitive dysfunction, abnormal TCD and prior stroke ${ }^{a}$

\begin{tabular}{|c|c|c|c|c|c|c|}
\hline & \multicolumn{3}{|c|}{ Unadjusted } & \multicolumn{3}{|c|}{ Adjusted* } \\
\hline & $\overline{\mathrm{OR}}$ & $95 \% \mathrm{Cl}$ & $p$-value & $\overline{\mathrm{OR}}$ & $95 \% \mathrm{Cl}$ & \\
\hline \multicolumn{7}{|c|}{ Neurocognitive Dysfunction ( $N=246$ ) } \\
\hline Age (years) & 1.44 & $1.23-1.68$ & $<0.0001$ & 1.50 & $1.26-1.79$ & $<0.0001$ \\
\hline Sex (male) & 1.01 & $0.45-2.24$ & 0.98 & - & - & - \\
\hline Hemoglobin (grams/dl) & 1.09 & $0.74-1.62$ & 0.65 & - & - & - \\
\hline Malnutrition (z-score) ${ }^{+}$ & 0.80 & $0.62-1.04$ & 0.09 & 0.83 & $0.59-1.17$ & 0.29 \\
\hline Abnormal TCD ${ }^{++}$ & 2.82 & $1.06-7.50$ & 0.04 & - & - & - \\
\hline Prior stroke & 6.67 & $2.16-20.6$ & 0.001 & 6.88 & $1.95-24.3$ & 0.003 \\
\hline \multicolumn{7}{|l|}{ Abnormal TCD $(\mathrm{N}=252)$} \\
\hline Age & 0.92 & $0.81-1.04$ & 0.19 & 0.90 & $0.77-1.05$ & 0.18 \\
\hline Sex & 0.90 & $0.45-1.82$ & 0.77 & - & - & - \\
\hline Hemoglobin (grams/dl) & 0.93 & $0.64-1.34$ & 0.69 & - & - & - \\
\hline Malnutrition & 1.37 & $1.01-1.86$ & 0.04 & 1.36 & $0.99-1.85$ & 0.05 \\
\hline Neurocognitive Dysfunction & 2.82 & $1.06-7.50$ & 0.04 & 4.37 & $1.30-14.7$ & 0.02 \\
\hline Prior stroke & 0.69 & $0.08-5.72$ & 0.74 & - & - & - \\
\hline \multicolumn{7}{|l|}{ Prior stroke $(N=264)$} \\
\hline Age & 1.12 & $0.94-1.34$ & 0.20 & 1.01 & $0.84-1.23$ & 0.86 \\
\hline Female Sex & 0.96 & $0.34-2.74$ & 0.94 & - & - & - \\
\hline Hemoglobin (grams/dl) & 1.19 & $0.73-1.95$ & 0.48 & - & - & - \\
\hline Malnutrition $^{+}$ & 0.81 & $0.58-1.13$ & 0.21 & - & - & - \\
\hline Abnormal TCD & 0.69 & $0.08-5.72$ & 0.73 & - & - & - \\
\hline Neurocognitive Dysfunction & 6.67 & $2.16-20.6$ & 0.0010 & 6.27 & $1.79-22.0$ & 0.004 \\
\hline
\end{tabular}

*For each outcome, adjusted models were constructed using each of risk factors collected (sex, age, hemoglobin and malnutrition) and other outcome(s) identified as associated in the univariable analyses. Hemoglobin and age were kept as continuous variables in the model

${ }^{+}$Defined per World Health Organization standards, by age and sex, for children 1-4 years and ages 5-12 years, as z-score of $\leq-2$ (ref. 28 )

${ }^{++}$TCD data refer to abnormal velocities, including those in the "conditional" and "abnormal" ranges for pediatric SCA (ref. 43) Individual and potentially overlapping associated risk factors collected were assessed separately for each of the three abnormal primary test results. Only neurocognitive dysfunction was significantly related to age and to abnormal results in each of the other tests. Malnutrition was associated with elevated TCD and showed a trend to neurocognitive dysfunction, while hemoglobin and age were not associated with any of the three primary results. Overall, the most significant predictor of poor outcome was other poor outcomes, holding age and malnutrition constant. Prior stroke was most strongly associated neurocognitive dysfunction. In contrast, prior stroke was not associated elevated TCD 
sample (Table 2). For this study, stroke findings were gauged as prior stroke or not.

\section{TCD: tester reliability}

Volunteers for testing operator reliability were 40 subjects ages 2-12 years and 10 young adults without SCA. The MCA right and left velocities measured by each examiner were normally distributed. Testers met criteria for high reliability for each MCA side tested, expressed by Cronbach's alpha was $\geq 0.85$ for each side tested [50].

\section{TCD examination}

We attempted to perform TCD testing on all subjects. Three were unable to schedule a TCD examination. Of 262 participants with attempted TCD testing, bilateral readings were obtained in 251 . Of the 11 participants whose TCDs were unable to be performed despite two separate testing sessions, nine had poor bone windows on one or both sides ("inadequate") one was uncooperative and one was younger than age 2 years.

Among 251 subjects with successful bilateral TAMV measurements, bilateral TCD velocities ranged from 93 to $250 \mathrm{~cm} / \mathrm{sec}$. Based on standardized velocities for pediatric SCD, [43] five subjects (2.1\%) had abnormal measures: $212-250 \mathrm{~cm} / \mathrm{sec}$. An additional $38(16.0 \%)$ had conditional results of $170-191 \mathrm{~cm} / \mathrm{sec}$ (Table 2), a total of 43 (18.1\%) with elevated velocities (Table 2). No participant had very low flow velocities. Age was not a risk factor for elevated velocity (Table 3, Fig. 1). Forty of 43 participants with elevated TCD returned within 1-3 months for repeat testing. Of the five subjects with an initial abnormal velocity, four remained in the abnormal range and one became conditional. Overall, 30 participants had velocities still above the limit for normal pediatric SCD [43]. Parents of these children agreed to the clinic's standard treatment regimen of hydroxyurea.

\section{MRI/MRA imaging}

A subset of 81 with MR imaging was enriched for MR imaging was enriched for those with one more abnormal primary test result, mean age $6.5 \pm 2.76$ years, 41 (50.1\%) male. In all, 42 had an abnormal scan (51.9\%). The ages of children with normal compared to abnormal MR imaging was not significantly different: age $6.0 \pm 2.99$ versus $6.8 \pm 2.24$ years.

Among the abnormal scans, one or more medium or large infarcts were seen in 35 (83\%), and multiple small infarcts in seven (17\%) [46]. MRA detected $\geq 1$ arterial stenosis in nine (21\%); all but two were accompanied by one or more infarcts. Of the 20 participants intentionally sampled for having normal results on all three of the primary tests, 12 were found to have 1-2 small cortical or $\geq 1$ subcortical infarcts. These subjects constituted an additional $4.5 \%$ of the overall sample with brain abnormalities detected. Statistical relationships between participants with abnormal imaging and each of the three primary other tests were not explored due to the non-random sampling.

\section{Descriptive and statistical analyses of primary results}

Overall, 57 (21.5\%) subjects had $\geq 1$ abnormal primary test result(s), 17 (6.9\%) had $\geq 2$ abnormal primary results and $2(1.0 \%)$ had all three abnormalities tested (Table 2). As expected by frequency, the most overlapping results were conditional TCD and neurocognitive impairment. Each continuous clinical variable (age, $\mathrm{Hb}$, malnutrition) was normally distributed. In a correlation analysis malnutrition was strongly associated with $\mathrm{Hb}(p=0.004)$ and older age $(p<0.001)$, but not with sex. Only neurocognitive dysfunction significantly increased with age (OR 1.44, 95\%CI 1.23-1.68, $\mathrm{p}<0.001$ ) (Table 3). In adjusted models, prior stroke was related to a six-fold increased risk of neurocognitive dysfunction $(p=.003)$, but not elevated TCD velocity. In addition, neurocognitive dysfunction was associated with elevated TCD velocity $(p=0.02)$, but not prior stroke (Table 3$)$.

Stroke was strongly related to neurocognitive impairment in univariate and adjusted models, as was elevated TCD $(p=0.003$; Table 3). Malnutrition was independently associated with elevated TCD $(p<0.04)$, but an association with neurocognitive impairment was not statistically significant. Other demographic (age, sex) and clinical variables ( $\mathrm{Hb}$ and malnutrition) had no significantly association. Relationships with the results of MR imaging were not examined due to non-random selection of the subsample of subjects with imaging.

Mortality and incident stroke

Over a 5-month observational period during completion of study procedures, three subject deaths (1.1\%) occurred. Of these deaths, two were attributable to acute stroke. By stroke examination, no prior stroke had been detected in either participant. One of the stroke deaths occurred in a child with an abnormal TCD, prior to return for repeat TCD testing and initiation of hydroxyurea. Etiology of the third death was a different SCA complication, acute chest syndrome. Based on these data, there were an estimated $1.8 \%$ strokes per year prorated from a 5-month observational period. No other strokes were known to have occurred during the study procedure period of this cross-sectional study by parental report or clinic-based follow-up.

\section{Discussion}

This study, BRAIN SAFE, used multiple standardized neurological and neurocognitive analyses to estimate neurological and neurocognitive impairment or risk. Our main finding was the high frequency - overall one in five - of one or more brain abnormalities tested, or 
one in four if including SCI from the subset with MRI/ MRA. Excluding the sampling for MR imaging, not many subjects had more than one abnormality detected.

Other key findings were: 1) only poor neurocognition depended on age, and rarely was found before age $5 ; 2$ ) neurocognitive impairment was strongly associated with abnormally high TCD velocity, also reported in the U.S. and Nigeria, [52, 53], and with stroke (reviewed in ref. 6); 3) malnutrition was also a marker of stroke risk; 4) severe anemia, a major risk factor for impaired neurocognition, abnormal TCD and SCI in pediatric SCA $[6,17,51,54]$, was seen in three-quarters of our sample; 5) some participants with normal neurological and neurocognitive testing were found to have cerebrovascular abnormalities on MR imaging. These results collectively suggest that Ugandan children with SCA are severely affected by brain abnormalities, and exhibit potentially modifiable risk factors of malnutrition and anemia. Lack of an age-dependent accumulation of prior stroke or elevated TCD velocity may reflect a possibility that large vessel disease predisposes to increased clinic drop-out or mortality.

Recent SCA studies in children of comparable ages in other African countries have reported similar or higher frequency of abnormal TCD results $[16,17,19,20$, 23].; some studies included neurocognitive assessments $[20,24]$. Testing restricted to one modality, e.g. TCD, may underestimate the effect of SCA on brain injury in African children $[16,18,55,56]$. We are aware of only one other African report which also includes SCA stroke examination and MR imaging [20] i.

The estimated mortality rate from deaths during our relatively brief observational period was comparable to that reported in a 36-month Nigerian study of children with SCA and similar age range [16]. Observed mortality in children of this age range is consistent with prior regional estimates for SCA $[57,58]$.

Our findings resemble U.S.-based natural history observations from a HbSS cohort: frequent severe SCA cerebral vasculopathy in early childhood, including abnormal MR imaging and neurocognitive function $[59,60]$. Important differences compared to the Dallas cohort and others were the suggestion of high mortality and lack of statistical association with low $\mathrm{Hb}[61,62]$. These differences may reflect the impact from additional risk factors in the region: endemic infections, pervasive severe anemia and frequent malnutrition [63].

\section{Study limitations}

Age of onset of the abnormalities detected could not be determined. Prior stroke may have been underestimated due to incomplete clinical documentation. Fnot been included. Distinction between $\mathrm{HbSS}$ and $\mathrm{HbSB}^{0}$ thalassemia was not evaluated; few of the latter would be expected in Uganda [2]. Subjects with very low $\mathrm{Hb}$ were unintentionally included due to inaccurate screening $\mathrm{Hb}$. Severe anemia and malnutrition appear to be common among the SCA clinic's pediatric patients. Two different measures of nutritional assessment, weight-for-height for ages 1-4 and BMI for ages 5-12, were used to take advantage of the more recent established data for agespecific international norms, and to align with the age ranges for the two neurocognitive testing batteries used. The newer data reflects improved rates of childhood mortality and health status seen over the past decade in Uganda and most of sub-Saharan Africa [64]. All three primary tests were not obtained for each participant due to logistic or technical rather than systematic challenges. The proportion of fetal hemoglobin ( $\mathrm{HbF} \%)$, an important disease modifier, was not obtained. In a sample of 216 children with SCA from the same clinic, mean age $9.3 \pm 4.8$ years, the mean $\mathrm{HbF} \%$ was $9.0 \pm 5.58$ [65] Alpha thalassemia trait also was not evaluated [19]. Other than the historic community controls for neurocognitive testing, local children lacking SCA were not assessed. Disease-related mortality may have skewed participants towards younger ages and survivors. Nonneurological factors contributing to abnormal neurocognitive testing were not assessed, e.g. socio-economic factors or parental education. MR imaging was not performed for all subjects, nor on a random sub-sample.

\section{Conclusions}

High frequency of neurological and neurocognitive results were found in a clinic-based sample of young children with SCA. Pediatric SCA stroke in highresource countries has markedly decreased, largely from primary prevention through TCD screening [43, $66,67]$ as well as increased use of hydroxyurea and other preventative health measures [68, 69]. Primary stroke prevention through use of hydroxyurea rather than chronic blood transfusions in low-resource settings appears to reduce TCD velocities and stroke risk [16, 18, 55]. Recent Africa-based treatment trials in SCA indicate its feasibility, including in Uganda $[27,70]$. Our findings, along with those cited herein, underscore the imperative testing the impact of hydroxyurea or other available disease-modifying interventions to reduce or prevent pediatric SCA brain vasculopathy in Africa.

\section{Supplementary information}

Supplementary information accompanies this paper at https://doi.org/10. 1186/s12887-019-1758-2.

Additional file 1. Transcranial doppler ultrasound: training and tester reliability. 


\section{Abbreviations}

CBC: Complete blood count; Hb: Hemoglobin; $\mathrm{HbSB}^{0}$

thalassemia: Compound heterozygous $\mathrm{HbS}$ and beta thalassemia 0; HbSS: Homozygous SCA; KABC-II: Kaufman Assessment Battery for Children, 2nd edition; MRI/MRA: Magnetic resonance imaging and angiography; PedNIHSS: Pediatric NIH Stroke Scale; SCA: Sickle cell anemia; TAMV: Timeaveraged maximum mean velocities; TCD: Transcranial Doppler; WHO: World Health Organization

\section{Acknowledgements}

We appreciate critical contributions from Latanya Bowman, RN, Augusta University Sickle Cell Center; Jose Gutierrez, MD, MPH, Columbia University Medical Center; support from Global Health Uganda and generous support from the participating families and staff from the Mulago Hospital Sickle Cell Clinic.

\section{Authors contributions}

NSG and RI contributed to study design, executed and analyzed all study aspects, data acquisition, drafted and edited the manuscript. DM, PB, RO contributed to study design, data acquisition and analysis, manuscript editing. LRB, BK, AB, MK, SKL, FM made major contributions to data acquisition. EM, PK, SK contributed to study design, data acquisition and analysis. $\mathrm{HH}, \mathrm{MSVE}, \mathrm{CR}, \mathrm{PL}$ contributed to study design and data interpretation. WP, GL, AB performed data analysis. RS and EK managed data capture, management, storage. All authors have made substantial contributions, and have read and approved the final manuscript.

\section{Funding}

This study was funded 1R21HD089791 (PIs Idro, Green) through the Fogarty Institute of the $\mathrm{NIH}$ and NICHD. The funder had no role in study design, data collection, analyses or interpretation, nor in writing the manuscript.

\section{Availability of data and materials}

Study materials used are available from the corresponding author upon reasonable request.

\section{Ethics approval and consent to participate}

Study protocols were approved by the Makerere School of Medicine Research and Ethics Committee (SOMREC, protocol 2016-081) and the Institutional Review Board of Columbia University protocol (AAAR0105). The Uganda National Council for Science and Technology also approved this study. Signed consent by parents (or official caretakers) and signed assent by children of sufficient age, as determined by the Makerere IRB, were obtained during study enrollment.

\section{Consent for publication}

This report includes no personal or identifying information for any single or small group of individual.

\section{Competing interests}

The authors declare that they have no competing interests.

\section{Author details}

${ }^{1}$ Department of Pediatrics, Columbia University Vagelos Medical Center, 630 West 168 St., Black Building 2-241, Box 168, New York, NY, USA. ²Department of Paediatrics and Child Health, Makerere University College of Health Sciences, Kampala, Uganda. ${ }^{3}$ Department of Psychiatry, Makerere University College of Health Sciences, Kampala, Uganda. ${ }^{4}$ Department Radiology, Makerere University College of Health Sciences, Kampala, Uganda. ${ }^{5}$ Department of Paediatrics, CHU Sainte-Justine, University of Montreal, Montreal, Canada. ${ }^{6}$ Departments of Neurology, Epidemiology and Biostatistics, Columbia University Vagelos Medical Center, New York, NY, USA. ${ }^{7}$ Department of Biostatistics, Mailman School of Public Health, Columbia University Vagelos Medical Center, New York, NY, USA. ${ }^{8}$ Epidemiology and of Clinical and Translation Science, University of Pittsburgh, Pittsburgh, PA, USA. ${ }^{9}$ Department of Pediatrics, Columbia University Vagelos Medical Center, New York, NY, USA. ${ }^{10}$ Department of Radiology, Yale University, New Haven, CT, USA. ${ }^{11}$ Department of Neurology, Columbia University Vagelos Medical Center, New York, NY, USA.
Received: 23 January 2019 Accepted: 9 October 2019

Published online: 25 October 2019

\section{References}

1. Piel FB, Hay SI, Gupta S, Weatherall DJ, Williams TN. Global burden of sickle cell anaemia in children under five, 2010-2050: modelling based on demographics, excess mortality, and interventions. PLoS Med. 2013;10(7): e1001484.

2. Ndeezi G, Kiyaga C, Hernandez AG, Munube D, Howard TA, Ssewanyana I, Nsungwa J, Kiguli S, Ndugwa CM, Ware RE, et al. Burden of sickle cell trait and disease in the Uganda sickle surveillance study (US3): a cross-sectional study. Lancet Glob Health. 2016;4(3):e195-200.

3. Ohene-Frempong K, Weiner SJ, Sleeper LA, Miller ST, Embury S, Moohr JW, Wethers DL, Pegelow CH, Gill FM. Cerebrovascular accidents in sickle cell disease: rates and risk factors. Blood. 1998:91(1):288-94.

4. Ware RE, de Montalembert M, Tshilolo L, Abboud MR. Sickle cell disease. Lancet. 2017;390(10091):311-23.

5. Balkaran B, Char G, Morris JS, Thomas PW, Serjeant BE, Serjeant GR. Stroke in a cohort of patients with homozygous sickle cell disease. J Pediatr. 1992; 120(3):360-6.

6. DeBaun MR, Kirkham FJ. Central nervous system complications and management in sickle cell disease. Blood. 2016;127(7):829-38

7. Kawadler JM, Kirkham FJ, Clayden JD, Hollocks MJ, Seymour EL, Edey R, Telfer $\mathrm{P}$, Robins A, Wilkey $\mathrm{O}$, Barker $\mathrm{S}$, et al. White matter damage relates to oxygen saturation in children with sickle cell Anemia without silent cerebral infarcts. Stroke. 2015:46(7):1793-9.

8. Kwiatkowski JL, Zimmerman RA, Pollock AN, Seto W, Smith-Whitley K, Shults J, Blackwood-Chirchir A, Ohene-Frempong K. Silent infarcts in young children with sickle cell disease. Br J Haematol. 2009;146(3):300-5.

9. van der Land V, Hijmans $C T$, de Ruiter M, Mutsaerts HJ, Cnossen MH, Engelen M, Majoie CB, Nederveen AJ, Grootenhuis MA, Fijnvandraat K. Volume of white matter hyperintensities is an independent predictor of intelligence quotient and processing speed in children with sickle cell disease. Br J Haematol. 2015;168(4):553-6.

10. Kawadler JM, Clayden JD, Clark CA, Kirkham FJ. Intelligence quotient in paediatric sickle cell disease: a systematic review and meta-analysis. Dev Med Child Neurol. 2016;58(7):672-9.

11. Jorgensen DR, Rosano C, Novelli EM. Can neuroimaging markers of vascular pathology explain cognitive performance in adults with sickle cell Anemia? A review of the literature. Hemoglobin. 2016;40(6):381-7.

12. Quinn $C T$, McKinstry RC, Dowling MM, Ball WS, Kraut MA, Casella JF, Dlamini $\mathrm{N}$, Ichord RN, Jordan LC, Kirkham FJ, et al. Acute silent cerebral ischemic events in children with sickle cell anemia. JAMA Neurol. 2013;70(1):58-65.

13. Marks LJ, Munube D, Kasirye P, Mupere E, Jin Z, LaRussa P, Idro R, Green NS: Stroke Prevalence in Children With Sickle Cell Disease in Sub-Saharan Africa A Systematic Review and Meta-Analysis: Glob Pediatr Health 2018, 5: $2333794 \times 18774970$

14. Noubiap JJ, Mengnjo MK, Nicastro N, Kamtchum-Tatuene J. Neurologic complications of sickle cell disease in Africa: a systematic review and metaanalysis. Neurology. 2017:89(14):1516-24.

15. Munube D, et al. Prevalence of stroke in children admitted with sickle cell Anaemia to Mulago hospital. BMC Neurol. 2016.

16. Galadanci NA, Umar Abdullahi S, Vance LD, Musa Tabari A, Ali S, Belonwu R, Salihu A, Amal Galadanci A, Wudil Jibir B, Bello-Manga H, et al. Feasibility trial for primary stroke prevention in children with sickle cell anemia in Nigeria (SPIN trial). Am J Hematol. 2017:92(8):780-8.

17. Lagunju I, Sodeinde O, Telfer P. Prevalence of transcranial Doppler abnormalities in Nigerian children with sickle cell disease. Am J Hematol. 2012;87(5):544-7.

18. Lagunju I, Brown BJ, Sodeinde O. Hydroxyurea lowers transcranial Doppler flow velocities in children with sickle cell anaemia in a Nigerian cohort. Pediatr Blood Cancer. 2015;62(9):1587-91.

19. Cox SE, Makani J, Soka D, L'Esperence VS, Kija E, Dominguez-Salas P, Newton CR, Birch AA, Prentice AM, Kirkham FJ. Haptoglobin, alphathalassaemia and glucose-6-phosphate dehydrogenase polymorphisms and risk of abnormal transcranial Doppler among patients with sickle cell anaemia in Tanzania. Br J Haematol. 2014:165(5):699-706.

20. Kija EN, Saunders DE, Munubhi E, Darekar A, Barker S, Cox TCS, Mango M, Soka D ${ }^{1}$, Komba J, Nkya DA Cox SE, Kirkham FJ, Newton CRJC ${ }^{1}$. Transcranial Doppler and Magnetic Resonance in Tanzanian Children With Sickle Cell 
Disease. Stroke. 2019 Jul;50(7):1719-1726. Epub 2019 Jun 14. DOl: https:// doi.org/10.1161/STROKEAHA.118.018920.

21. Makani J, Kirkham FJ, Komba A, Ajala-Agbo T, Otieno G, Fegan G, Williams TN, Marsh K, Newton CR. Risk factors for high cerebral blood flow velocity and death in Kenyan children with sickle cell Anaemia: role of haemoglobin oxygen saturation and febrile illness. Br J Haematol. 2009;145(4):529-32.

22. Adekunle MO, Animasahun AB, Diaku-Akinwumi IN, Njokanma OF. Pattern of cerebral blood flow velocity using Transcranial Doppler ultrasonography in children with sickle cell disorder in Lagos state Nigeria. Mediterr J Hematol Infect Dis. 2017:9(1):e2017050.

23. Soyebi K, Adeyemo T, Ojewunmi O, James F, Adefalujo K, Akinyanju O, Capacity building and stroke risk assessment in Nigerian children with sickle cell anaemia. Pediatr Blood Cancer. 2014;61(12):2263-6.

24. Oluwole OB, Noll RB, Winger DG, Akinyanju O, Novelli EM. Cognitive functioning in children from Nigeria with sickle cell anemia. Pediatr Blood Cancer. 2016;63(11):1990-7.

25. Ogunseyinde AO, Obajimi MO, Fatunde OJ. Computed tomographic pattern of stroke in children with sickle cell anaemia in Ibadan. Afr J Med Med Sci. 2005;34(2):115-8.

26. Anyanwu JN, Williams $\mathrm{O}$, Sautter $\mathrm{CL}$, Kasirye P, Hume H, Opoka RO, Latham T, Ndugwa C, Ware RE, John CC. Novel use of Hydroxyurea in an African region with malaria: protocol for a randomized controlled clinical trial. JMIR Res Protoc. 2016;5(2):e110.

27. Opoka RO, Ndugwa CM, Latham TS, Lane A, Hume HA, Kasirye P, Hodges JS, Ware RE, John CC. Novel use of Hydroxyurea in an African region with malaria (NOHARM): a trial for children with sickle cell anemia. Blood. 2017.

28. https://www.who.int/childgrowth/standards/technical_report/en, 2009.

29. Rana S, Houston PE, Wang WC, lyer RV, Goldsmith J, Casella JF, Reed CK, Rogers ZR, Waclawiw MA, Thompson B, et al. Hydroxyurea and growth in young children with sickle cell disease. Pediatrics. 2014; 134(3):465-72.

30. Ruel TD, Boivin MJ, Boal HE, Bangirana P, Charlebois E, Havlir DV, Rosenthal PJ, Dorsey G, Achan J, Akello C, et al. Neurocognitive and motor deficits in HIV-infected Ugandan children with high CD4 cell counts. Clin Infect Dis. 2012;54(7):1001-9.

31. Idro R, Kakooza-Mwesige A, Asea B, Ssebyala K, Bangirana P, Opoka RO, Lubowa SK, Semrud-Clikeman M, John CC, Nalugya J. Cerebral malaria is associated with long-term mental health disorders: a cross sectional survey of a long-term cohort. Malar J. 2016;15:184.

32. Ssenkusu JM, Hodges JS, Opoka RO, Idro R, Shapiro E, John CC, Bangirana P. Long-term Behavioral Problems in Children With Severe Malaria. Pediatrics. 2016;138(5).

33. Bangirana P, Opoka RO, Boivin MJ, Idro R, Hodges JS, Romero RA, Shapiro E, John CC: Severe malarial anemia is associated with long-term neurocognitive impairment. Clinical Infectious Diseases 2014:doi: https://doi. org/10.1093/cid/ciu1293-doi: 1010.1093/cid/ciu1293.

34. Bangirana P, Musisi S, Allebeck P, Giordani B, John C, Opoka O, Byarugaba J, Ehnvall A, Boivin M. A preliminary examination of the construct validity of the KABC-II in Ugandan children with a history of cerebral malaria. Afr Health Sci. 2009;9(3).

35. Mullen EM: Mullen Scales of Early Learning:AGS Edition.; 1995.

36. Mullen EM: Mullen scales of early learning item administration book, AGS edn. Circle Pines, MN: American Guidance Service; 1995.

37. Kaufman AS, Kaufman NL: KABC-II : Kaufman assessment battery for children. In., 2nd edn. Circle Pines, MN: AGS Pub.; 2004.

38. Kaufman AS, Kaufman NL: Kaufman assessment battery for children manual, 2 edn. Circle Pines, MN: American Guidance Service; 2004.

39. Beslow LA, Kasner SE, Smith SE, Mullen MT, Kirschen MP, Bastian RA, Dowling MM, Lo W, Jordan LC, Bernard TJ, et al. Concurrent validity and reliability of retrospective scoring of the pediatric National Institutes of Health stroke scale. Stroke. 2012;43(2):341-5.

40. Ichord RN, Bastian R, Abraham L, Askalan R, Benedict S, Bernard TJ, Beslow L, Deveber $G$, Dowling M, Friedman N, et al. Interrater reliability of the pediatric National Institutes of Health stroke scale (PedNIHSS) in a multicenter study. Stroke. 2011;42(3):613-7.

41. Kinney TR, Sleeper LA, Wang WC, Zimmerman RA, Pegelow CH, OheneFrempong K, Wethers DL, Bello JA, Vichinsky EP, Moser FG, et al. Silent cerebral infarcts in sickle cell anemia: a risk factor analysis. The cooperative study of sickle cell disease. Pediatrics. 1999;103(3):640-5.

42. Idro R, Gwer S, Kahindi M, Gatakaa H, Kazungu T, Ndiritu M, Maitland K, Neville BG, Kager PA, Newton CR. The incidence, aetiology and outcome of acute seizures in children admitted to a rural Kenyan district hospital. BMC Pediatr. 2008:8:5.

43. Adams RJ, McKie VC, Hsu L, Files B, Vichinsky E, Pegelow C, Abboud M, Gallagher D, Kutlar A, Nichols FT, et al. Prevention of a first stroke by transfusions in children with sickle cell anemia and abnormal results on transcranial Doppler ultrasonography. N Engl J Med. 1998;339(1):5-11.

44. Pavlakis SG, Rees RC, Huang X, Brown RC, Casella JF, Iyer RV, Kalpatthi R, Luden J, Miller ST, Rogers ZR, et al. Transcranial doppler ultrasonography (TCD) in infants with sickle cell anemia: baseline data from the BABY HUG trial. Pediatr Blood Cancer. 2010;54(2):256-9.

45. Galadanci NA, Abdullahi SU, Tabari MA, Abubakar S, Belonwu R, Salihu A, Neville K, Kirkham F, Inusa B, Shyr Y, et al. Primary stroke prevention in Nigerian children with sickle cell disease (SPIN): challenges of conducting a feasibility trial. Pediatr Blood Cancer. 2015;62(3):395-401.

46. Helton KJ, Adams RJ, Kesler KL, Lockhart A, Aygun B, Driscoll C, Heeney MM, Jackson SM, Krishnamurti L, Miller ST, et al. Magnetic resonance imaging/ angiography and transcranial Doppler velocities in sickle cell anemia: results from the SWiTCH trial. Blood. 2014;124(6):891-8,

47. Adams RJ, Brambilla DJ, Granger S, Gallagher D, Vichinsky E, Abboud MR, Pegelow CH, Woods G, Rohde EM, Nichols FT, et al. Stroke and conversion to high risk in children screened with transcranial Doppler ultrasound during the STOP study. Blood. 2004;103(10):3689-94.

48. Green NS, Bhatia M, Griffith EY, Qureshi M, Briamonte C, Savone M, Sands S, Lee MT, Lignelli A, Brickman AM. Enhanced long-term brain magnetic resonance imaging evaluation of children with sickle cell disease after hematopoietic cell transplantation. Biol Blood Marrow Transplant. 2017;23(4):670-6.

49. Wolfe RA. The standardized mortality ratio revisited: improvements, innovations, and limitations. Am J Kidney Dis. 1994;24(2):290-7.

50. Tavakol M, Dennick R. Making sense of Cronbach's alpha. Int J Med Educ. 2011;2:53-5.

51. Hijmans CT, Grootenhuis MA, Oosterlaan J, Heijboer H, Peters M, Fijnvandraat K. Neurocognitive deficits in children with sickle cell disease are associated with the severity of anemia. Pediatr Blood Cancer. 2011;57(2): 297-302.

52. Bernaudin F, Verlhac S, Arnaud C, Kamdem A, Vasile M, Kasbi F, Hau I, Madhi F, Fourmaux C, Biscardi S, et al. Chronic and acute anemia and extracranial internal carotid stenosis are risk factors for silent cerebral infarcts in sickle cell anemia. Blood. 2015;125(10):1653-61.

53. Kwiatkowski JL, Yim E, Miller S, Adams RJ, Investigators SS. Effect of transfusion therapy on transcranial Doppler ultrasonography velocities in children with sickle cell disease. Pediatr Blood Cancer. 2011;56(5):777-82.

54. Brousse $\mathrm{V}$, Kossorotoff $\mathrm{M}$, de Montalembert M. How I manage cerebral vasculopathy in children with sickle cell disease. $\mathrm{Br} J$ Haematol. 2015; 170(5):615-25.

55. Rankine-Mullings AE, Morrison-Levy N, Soares D, Aldred K, King L, Ali S, Knight-Madden JM, Wisdom-Phipps M, Adams RJ, Ware RE, et al. Transcranial Doppler velocity among Jamaican children with sickle cell anaemia: determining the significance of haematological values and nutrition. Br J Haematol. 2018;181(2):242-51.

56. Prussien KV, Salihu A, Abdullahi SU, Galadanci NA, Bulama K, Belonwu RO, Kirkham FJ, Yarboi J, Bemis H, DeBaun MR, et al. Associations of transcranial doppler velocity, age, and gender with cognitive function in children with sickle cell anemia in Nigeria. Child Neuropsychol. 2018:1-16.

57. Grosse SD, Odame I, Atrash HK, Amendah DD, Piel FB, Williams TN. Sickle cell disease in Africa: a neglected cause of early childhood mortality. Am J Prev Med. 2011:41(6 Suppl 4):S398-405.

58. Makani J, Cox SE, Soka D, Komba AN, Oruo J, Mwamtemi H, Magesa P, Rwezaula S, Meda E, Mgaya J, et al. Mortality in sickle cell anemia in Africa: a prospective cohort study in Tanzania. PLoS One. 2011;6(2):e14699.

59. Moser FG, Miller ST, Bello JA, Pegelow CH, Zimmerman RA, Wang WC, Ohene-Frempong K, Schwartz A, Vichinsky EP, Gallagher D, et al. The spectrum of brain MR abnormalities in sickle-cell disease: a report from the cooperative study of sickle cell disease. AJNR Am J Neuroradiol. 1996;17(5):965-72.

60. Armstrong FD, Thompson RJ Jr, Wang W, Zimmerman R, Pegelow $\mathrm{CH}$, Miller S, Moser F, Bello J, Hurtig A, Vass K. Cognitive functioning and brain magnetic resonance imaging in children with sickle cell disease. Neuropsychology Committee of the Cooperative Study of sickle cell disease. Pediatrics. 1996;97(6 Pt 1):864-70. 
61. Quinn CT, Lee NJ, Shull EP, Ahmad N, Rogers ZR, Buchanan GR. Prediction of adverse outcomes in children with sickle cell anemia: a study of the Dallas newborn cohort. Blood. 2008;111(2):544-8.

62. Meier ER, Wright EC, Miller JL. Reticulocytosis and anemia are associated with an increased risk of death and stroke in the newborn cohort of the cooperative study of sickle cell disease. Am J Hematol. 2014;89(9):904-6.

63. Bello-Manga H, DeBaun MR, Kassim AA. Epidemiology and treatment of relative anemia in children with sickle cell disease in sub-Saharan Africa. Expert Rev Hematol. 2016;9(11):1031-42.

64. https://www.unicef.org/mdg/index_childmortality.htm

65. Mpalampa L, Ndugwa CM, Ddungu H, Idro R. Foetal haemoglobin and disease severity in sickle cell anaemia patients in Kampala. Uganda BMC Blood Disord. 2012;12:11. https://doi.org/10.1186/1471-2326-12-11.

66. Adams RJ, McKie VC, Carl EM, Nichols FT, Perry R, Brock K, McKie K, Figueroa $\mathrm{R}$, Litaker $\mathrm{M}$, Weiner $\mathrm{S}$, et al. Long-term stroke risk in children with sickle cell disease screened with transcranial Doppler. Ann Neurol. 1997;42(5):699-704.

67. Bernaudin F, Verlhac S, Arnaud C, Kamdem A, Hau I, Leveille E, Vasile M, Kasbi F, Madhi F, Fourmaux C, et al. Long-term treatment follow-up of children with sickle cell disease monitored with abnormal transcranial Doppler velocities. Blood. 2016;127(14):1814-22.

68. Hankins JS, McCarville MB, Rankine-Mullings A, Reid ME, Lobo CL, Moura PG, Ali S, Soares DP, Aldred K, Jay DW, et al. Prevention of conversion to abnormal transcranial Doppler with hydroxyurea in sickle cell anemia: a phase III international randomized clinical trial. Am J Hematol. 2015;90(12): 1099-105.

69. Yawn BP, Buchanan GR, Afenyi-Annan AN, Ballas SK, Hassell KL, James AH, Jordan L, Lanzkron SM, Lottenberg R, Savage WJ, et al. Management of sickle cell disease: summary of the 2014 evidence-based report by expert panel members. JAMA. 2014;312(10):1033-48.

70. Tshilolo L, Tomlinson G, Williams TN, Santos B, Olupot-Olupot P, Lane A, Aygun B, Stuber SE, Latham TS, McGann PT, et al. Hydroxyurea for children with sickle cell Anemia in sub-Saharan Africa. N Engl J Med. 2019:380(2):121-31.

\section{Publisher's Note}

Springer Nature remains neutral with regard to jurisdictional claims in published maps and institutional affiliations.

Ready to submit your research? Choose BMC and benefit from:

- fast, convenient online submission

- thorough peer review by experienced researchers in your field

- rapid publication on acceptance

- support for research data, including large and complex data types

- gold Open Access which fosters wider collaboration and increased citations

- maximum visibility for your research: over $100 \mathrm{M}$ website views per year

At $\mathrm{BMC}$, research is always in progress.

Learn more biomedcentral.com/submissions 